\title{
Implementation of Principal Academic Supervision to Improve the Teacher Performance in Online Learning During the Covid-19 Pandemic
}

\author{
Rusmiati $^{\left.1^{*}\right)}$, Edi Haparan ${ }^{2}$, Nila Kesumawati ${ }^{2}$
}

\author{
${ }^{1}$ SMPN 2 Suak Tapeh \\ ${ }^{2}$ Universitas PGRI Palembang \\ *Corresponding author. E-mail: rrusmiati422@gmail.com
}

\begin{abstract}
This study aims to determine and describe the implementation of academic supervision of principals to improve teacher performance in online learning during the Covid 19 pandemic at SMPNegeri 2 Betung. This type of research is descriptive qualitative research. Collecting data using documentation, interviews, observation and literature review. The results of the study stated that: (1) The planning for the implementation of the principal's academic supervision was scheduled before the new academic year began, (2) it was carried out in accordance with the teaching and learning process which was directed at the pandemic, where teachers had used IT infrastructure in the learning process. teaching, (3) Evaluation of the results of the academic supervision process has been carried out, as evidenced by the implementation of clinical supervision, (4) based on the results of this study it can also be stated that the performance of teachers in implementing online learning is already in good condition, the implication of this research is that there are still teachers who do not understand the making of learning administration. Advice for Teachers, can independently increase professionalism by trying to use new applications.
\end{abstract}

Keywords: Academic Supervision, Performance, Online Learning

\section{INTRODUCTION}

The world is facing an outbreak of the Covid-19 virus, the spread of which is almost evenly distributed throughout the country. Our country has not been spared from this epidemic which has an impact on various sectors, including the education sector. Nadiem Anwar Makarim took a policy of stopping face-to-face schooling activities which were replaced by distance learning [1].

Supervision activities should be carried out continuously whether requested or not, because supervision is not an activity to spy on teachers but as an assistance provided to improve teaching-learning situations. The improvement of the teaching and learning situation is broadly defined not only as coaching the curriculum, improving PBM and developing teachers, but also improving the motivation and morale of teachers. Therefore, efforts are made to provide supervision services to all teachers and be provided individually [1].

Online learning was first known because of the influence of the development of electronic-based learning (e-learning) introduced by the University of Illinois through a computer-based learning system, where the learning material being studied is more varied, not only verbal, but more varied such as visual, audio, and motion [2].

So far, online learning is only as a concept, as a technical tool, not as a way of thinking, as a learning paradigm, whereas, online learning is not a method for changing face-to-face learning with online applications, nor is it burdening students with tasks that pile up every day [3].

By paying attention to the conditions that occur in the above background, this is what underlies researchers to find clearer and factual information regarding the implementation of school principal academic supervision to improve teacher performance in online learning during the Covid 19 pandemic at SMPNegeri 2 Betung.

\subsection{Research focus}

To clarify the scope of the problem to be discussed and so that the research is carried out in a focused manner, the problem boundaries in the research carried out relate to: (1) the implementation of academic supervision of the principal to improve teacher performance in online learning during the Covid 19 pandemic at SMP Negeri 2 Betung, (2) ) Teacher performance in online learning. 


\subsection{Research purposes}

The objectives of this study are: (1) To determine and describe the implementation of academic supervision of principals to improve teacher performance in online learning during the COVID-19 pandemic at state junior high school 2, sub-district Betung, (2) to describe teacher performance in online learning during the COVID-19 pandemic at state junior high school 2, sub-district Betung.

\section{THEORETICAL REVIEW}

\subsection{Definition of learning}

Learning is a system, which consists of various components that are interconnected with one another. These components include: objectives, materials, methods and evaluation. The four components of learning must be considered by the teacher in choosing and determining what media, methods, strategies, and approaches will be used in learning activities. [4]

In learning, the word learning is a translation of instructions that are widely used in the world of education. Whereas teaching is part of learning (instruction), where the role of the teacher is more emphasized on how to design or manage various sources and facilities available to then be used by students or students in learning something [5]

The word learning is a translation of instruction which is widely used in the world of education. Whereas teaching is part of learning (instruction), where the role of the teacher is more emphasized on how to design or arrange various sources and facilities available for later use by students or students in learning something. [5]

\subsection{Online Learning Concepts}

The current pandemic condition requires educators, in this case, teachers to innovate in changing face-toface learning patterns into face-to-face learning patterns. [6]explain that there are other learning models that can be used by teaching staff as a medium for delivering knowledge, namely online learning and mixed learning (a combination of two learning methods, namely faceto-face and online learning).

Online learning or e-learning is a form of learning model that is facilitated and supported by the use of information and communication technology. Elearning can be defined as a form of information technology applied in education in the form of cyberspace. [7]

\subsection{Activities in the Learning Process}

This activity is closely related to the duties of a teacher. The task of a teacher as an educator must be managed administratively to ensure the smooth implementation of learning in class. As for these tasks, among others: (1) Compiling a program implementation plan, (2) Arranging a schedule for implementing learning activities, (3) Filling in the learning progress assessment list.

\subsection{Study From Home}

Paragraph 3 of 2020 explains that "these large-scale social restrictions include at least school and work holidays, restrictions on religious activities, and / or restrictions on activities in public places or facilities." This resulted in temporary learning not being carried out at school. Therefore, learning must be done in each home (study from home[6]

\subsection{Definition of Teacher}

According to Noor Jamaluddin teachers are educators, adults who are responsible for providing guidance or assistance to students in the development of body and soul to reach maturity, able to stand alone to carry out their duties as khalifah of Allah on earth, as social beings and individuals who are able to stand alone. [8]

According to Dri Atmaka, educators are people who are responsible for providing assistance to students in both physical and spiritual development [8]

\subsection{Definition of teacher performance}

According to [9] primary school teacher work, focused on meaningful learning for students. [10], that learning must meet process standards including planning the learning process, implementing the learning process, assessing learning outcomes for the implementation of an effective and efficient learning process[9]

\subsection{Teacher performance appraisal}

The teacher performance appraisal can be broadly grouped into six main parts, namely: (1) planning learning, (2) implementing learning, (3) evaluating or assessing learning outcomes, (4) guiding extracurricular activities, (5) guiding novice teachers, and (6) selfdevelopment.

It can be concluded that teacher performance is the work achieved by the teacher in learning.

\subsection{Factors Affecting Teacher performance}

According to Suharsaputra's opinion, it is influenced by: (1) individual variables, (2) organizational variables, (3) psychological variables. [11]. argues that the factors that affect teacher performance include [12].

[13]. suggests the factors that affect teacher performance include: (1) personal or individual factors, (2) leadership factors (3) team factors, (4) system factors [12].

So, being a good and professional teacher is not only able to communicate with the classroom and school environment, but also has good relations with the surrounding community. can be a source of inspiration for the community and make a positive contribution.

Fathurrochman [13] explained the title Utilizing Information and Communications Technology as a Learning Source in the Digital Age. The results of the study indicate that ICT has many impacts on the development of the learning process [13]

According to [14] in its conclusion, it explains that in order to prepare an online learning system, universities must make a lot of preparations, such as 
improvements and revitalization, both in terms of infrastructure, infrastructure and resources. Indeed, to face the digital era, adjustments must be made as quickly as possible because technology is developing so fast that it is unable to be contained.

Research results state that the policy of studying at home in educational institutions clearly causes major disruptions, such as student learning, disruption in assessment.

[4] Review of implementation, challenges, and online learning solutions The results show that teachers implement government policies through online learning. Various platforms are used in online learning.

The similarities of the above research with the research that will be examined both make learning during the Covid 19 pandemic the object of research. The difference is that the research above analyzes the impact of Covid-19 on education in Indonesia. This study analyzes the implementation of the principal's academic supervision to improve teacher performance in online learning during the Covid-19 pandemic.

\section{METHODS}

This research was conducted at state junior high school 2, sub-district Betung, Banyuasin Regency. July 2020 to January 2021.

\subsection{Research methods}

In this study is a qualitative descriptive study with a case study approach, with a qualitative descriptive approach, analyzing the data obtained (in the form of words, pictures or behavior), and not written in the form of numbers or statistical figures, but by providing Exposure or depiction of the situation or condition under study in the form of a narrative description. The explanation must be done objectively so that the researcher's subjectivity in making interpretations can be avoided [5]

\subsection{Data and data sources}

The data sources in this study are the subjects from which data can be obtained, whether questionnaires or interviews.

Primary data sources were obtained by interviewing several informants. According to [7] the interviews used are semi-structured interviews. In semi-structured interviews, the questions are open but there are limitations to the theme and flow of the conversation. There is an interview guide that becomes a benchmark in the flow, order and use of words [6]

Table 1. The Informants of Research

\begin{tabular}{|l|l|l|}
\hline No. & \multicolumn{1}{|c|}{ Informant name } & \multicolumn{1}{c|}{ Information } \\
\hline 1. & Siti Nurbaya, S.Pd., M.Si & Key Informants \\
\hline 2. & Fitriana Yusnita, S.Pd. & Supporting informants \\
\hline 3. & Arafik, S.Pd & Supporting informants \\
\hline 4. & Ariyanti, S.Pd. & Supporting informants \\
\hline
\end{tabular}

Sources of secondary data obtained by researchers are data obtained from related parties, in the form of school data and various literature relevant to the discussion, such as documents at state junior high school 2, sub-district Betung.

\subsection{Data collection technique}

Table 2. Topics Interview For The Implementation Of The Academic Supervision Planning

\begin{tabular}{|c|c|c|c|}
\hline No. & indicator & Question & Key Informants \\
\hline 1. & $\begin{array}{l}\text { Supervision } \\
\text { schedule }\end{array}$ & $\begin{array}{l}\text { What is the planning for academic supervision } \\
\text { during the Pandemic }\end{array}$ & \multirow{7}{*}{ Headmaster } \\
\hline 2. & $\begin{array}{l}\text { Determination } \\
\text { of instruments }\end{array}$ & How do you do monitoring instruments & \\
\hline 3. & $\begin{array}{l}\text { Implementation } \\
\text { of supervision }\end{array}$ & When do you carry out your supervision? & \\
\hline 4. & Follow-up & $\begin{array}{l}\text { How do you follow up when there are findings } \\
\text { during the implementation of the lesson? }\end{array}$ & \\
\hline 5. & $\begin{array}{l}\text { Planning } \\
\text { leaming }\end{array}$ & $\begin{array}{l}\text { How do the teachers here plan the } \\
\text { implementation of online learning during this } \\
\text { Pandemic? }\end{array}$ & \\
\hline 6. & $\begin{array}{l}\text { Implementation } \\
\text { oflearning }\end{array}$ & $\begin{array}{l}\text { How are teachers implementing online } \\
\text { leaming during this Pandemic? }\end{array}$ & \\
\hline 7. & $\begin{array}{l}\text { Process } \\
\text { evaluation }\end{array}$ & $\begin{array}{l}\text { How teachers plan to carry out evaluation of } \\
\text { online leaming during the Pandemic }\end{array}$ & \\
\hline
\end{tabular}

\section{RESULTS AND DISCUSSION}

4.1 Implementation of Academic Supervision Planning at state junior high school 2, subdistrict Betung

According to the key informant (Ibu Siti Nurbaya), the formulation of the academic supervision schedule program is carried out at the beginning of the school year so that the program of supervision activities can be integrated into school activities as a whole.

He further argued that to supervise all teachers alone in one semester, a team that helps both at the beginning of planning, implementation and evaluation of academic supervision is needed. They are involved in academic supervision activities according to their abilities.

The schedule for class visits is eliminated because of the teaching and learning process through online activities. Therefore, supervision of class visits is only on examining documents and implementing learning by the teacher.

Then the principal formulates what techniques and approaches the principal will use in conducting evaluations, the findings of teacher problems related to the preparation of online learning tools based on the 2013 curriculum, namely the teacher does not fully understand the administration of making 2013 curriculum learning tools.

The results of the interview with Mrs. Fitriana Yusnita, S.Pd as the deputy head of sate Junior high school 2, sub-district Betung. which stated that at the beginning of each supervision activity, the principal had formulated supervision activities that referred to the concept of formulating previously held supervision activities.

The results of the interview with Mr. Arafik, S.Pd before the implementation of the supervision, the principal had first given a decree (SK) regarding the composition of the team that helped the principal in 
evaluation activities consisting of several teachers and also the arrangement of academic supervision activities accompanied by the implementation schedule.

\subsection{Implementation of Academic Supervision at state junior high school 2, sub-district Betung}

The implementation of academic supervision carried out by the principal includes teacher teaching planning, teacher teaching implementation and teacher teaching evaluation. At this stage, teachers are asked to prepare and fill out a checklist according to the supervision instrument. Based on the results of an interview with Ms. Siti Nurbaya, S.Pd, M.Si, she stated that there were still many deficiencies that had to be fixed.

The results of interviews with Mr. Arafik, S.Pd, the principal and the team discussed with the teacher what were the deficiencies in lesson planning.

From data collection through documentation of teacher RPP assessments that have been carried out by the principal, the results are good. The results of the assessment become a reference for teachers to improve the preparation of lesson plans in accordance with the 2013 curriculum [16].

The results of the interview with Mr. Arafik, S.Pd, he stated that the process of assessing the lesson plans carried out by the principal was based on the assessment guidelines, namely the lesson plan supervision instrument as an assessment reference.

Then the results of the interview with Mrs. Ariyanti, S.Pd, she stated that with the supervision of learning tools, especially lesson plans, teachers would better understand what the teacher lacks in preparing lesson plans.

\subsection{Implementation of Online Learning Supervision}

In the process of implementing learning supervision, the principal makes observations using the learning process assessment instrument.

Based on the results of the interview with the head of the school, he stated that the supervision of the learning process begins by inviting the teacher to prepare online-based learning according to the specified schedule, this is in line with the interviews conducted with supporting informants 1 and 2 . The principal makes visits to the class for assessment of the intended teacher.

From the results of the supervision, it was stated that online learning at state junior high school,2 subdistrict Betung had been running according to the teaching and learning process which was directed during the pandemic. Teachers have used IT infrastructure in the teaching and learning process.

The results of this study are supported by research which states that there is a significant positive relationship between academic supervision and the effectiveness of teacher learning [17].

The initial activity carried out by the principal is forming a team that helps the principal to formulate supervision activities to follow up on the results of academic supervision

The above statement is supported by the results of research conducted by (Ajasan, 2016) [18].

Based on the results of the research, it can be argued that the target of academic supervision carried out by the principal aims to foster teachers to be more skilled and competent in carrying out their duties.

This is in line with Olivia [18], which states that academic supervision activities are intended to help teachers: (1) plan, (2) present, (3) evaluate, (4) manage classes, (5) develop curriculum, (6) ) evaluating the curriculum, (7) evaluating yourself, (8) working with groups, (9) through inservise programs [19].

\section{CONCLUSION}

The difference between the impact of COVID-19 on the online learning process is felt by students, parents and teachers. With the online learning method, teachers, parents and students need time to adapt, in an effort to increase all the potential of students. Therefore, teachers must be ready to face these changes. The implementation of school principal academic supervision to improve teacher performance in online learning during the Covid 19 pandemic at state junior high school,2 sub-district Betung is the answer to this situation. The results are: (1) The planning for the implementation of the principal's academic supervision has been scheduled before the school year begins, (2) it has been running according to the teaching and learning process directed at the pandemic, where teachers have used IT infrastructure in the teaching and learning process.

Researcher's suggestions for: (1) school principals, in order to provide training and other activities that can help teachers overcome problems in the online learning process. (2) Teachers, can increase professionalism independently by using new applications, (3) further researchers, in order to use this research as a reference for further research, especially regarding the implementation of teacher academic supervision

\section{REFERENCES}

[1]. Winaryati, E. (2012). The competence of the principal as a supervisor in junior high school science learning in the city of Semarang. Paper presented at the prosiding of national \& international seminars.

[2]. Yuliani, M., Simarmata, J., Susanti, SS, Mahawati, E., Sudra, RI, Dwiyanto, H.,. . . Yuniwati, I. (2020). Online Learning for Education: Theory and Application: Our Foundation for Writing.

[3]. Mastur, M., Afifulloh, M., \& Dina, LNAB (2020). Teachers 'efforts in implementing online learning in the covid-19 Pandemic. JPMI: Journal of Madrasah Ibtidaiyah Education, 2 (3), 72-81. 
[4]. Musyafaah, I. (2017). Curriculum Management (Research at MI Islamiyah 01 Lebaksiu Kidul Tegal). Uin Sunan Gunung Djati Bandung.

[5]. Prastowo, A. (2013). Development of thematic teaching materials: Yogyakarta: Diva Press.

[6]. Handarini, OI, \& Wulandari, SS (2020). Online Learning as a Study From Home (SFH) Effort During the Covid Pandemic 19. Journal of Office Administration Education (JPAP), 8 (3), 496503.

[7]. Hanum, NS (2013). The effectiveness of elearning as a learning medium (evaluation study of the e-learning learning model of SMK Telkom Sandhy Putra Purwokerto). Journal of Vocational Education, 3 (1).

[8]. Nafrin, I., Kaunang, N., \& Santie, Y. (2018). The Role Of Civil Education Teachers In Improving Student Disciplines Of Kulisusu 1st High School, Buton Utara District, Tenggara Province. Journal of Civic Education: Media of Pancasila and Citizenship Studies, 2 (2), 62-68.

[9]. Kristiawan, M., \& Lian, B. (2019). The Correlation Between Supervision of Headmaster and Interpersonal Communication With Work Ethos of the Teacher. European Journal of Education Studies.

[10]. Permendiknas Nomor 16 Tahun 2005 tentang Standar Kualifikasi dan Kompetensi Pendidik.

[11]. Karweti, E. (2010). The influence of principal managerial ability and factors that influence work motivation on the performance of special school teachers in Subang Regency. Journal of educational research, 11 (2), 77-89.

[12]. Istiarini, R., \& Sukanti, S. (2012). The Effect of Teacher Certification and Teacher Work Motivation on Teacher Performance in SMA Negeri 1 Sentolo, Kulon Progo Regency in 2012. Journal of Indonesian Accounting Education, 10 (1).

[13]. D. H. Ristianti. (2017). “Analisis Hubungan Interpersonal Mahasiswa terhadap Dosen dalam Proses Bimbingan Skripsi," Islam. Couns. J. Bimbing. Konseling Islam, vol. 1, no. 1, p. 25.

[14]. S. Telaumbanua, G. Sianipar, M. Sarlin, A. Afdaliah, and I. Fathurrochman. (2020). "Conversational Implicatures Students Communication and Type: A Pragmatic Study in its," Int. J. Innov. Creat. Chang., vol. 13, no. 10, pp. 1294-1310.

[15]. D. H. Ristianti, R. Hidayat, B. Azwar, and I. Fathurrochman. (2019). "Assessment Aspects Counselling Activities of Group," Int. J. Innov. Creat. Chang., vol. 5, no. 6, pp. 1053-1063.

[16]. I. Fathurrochman, S. Danim, S. Anwar AB, N. Kurniah, and D. H. Ristianti. (2021). "Theoretical Review of the Implementation Islamic Boarding School Curriculum Management in Indonesia," Int. J. Educ. Res. Dev., vol. 1, no. 1, pp. 1-15.
[17]. I. Fathurrochman, S. Danim, S. Anwar AB, and N. Kurniah. (2021). "The School Principals' Role in Education Management at the Regional Level : An Analysis of Educational Policy in the Industrial Revolution 4 . 0," Adv. Soc. Sci. Educ. Humanit. Res., no. 532, pp. 237-242.

[18]. Erwin, Y., Arafat, Y., \& Wardiah, D. (2020). Utilization of information and communications technology as a resource for learning in the digital era. Jmksp (Journal of Management, Leadership, and Educational Supervision), 6 (1), 44-51.

[19]. Suci, MP (2020). The effectiveness of networkbased learning in insya"s course at stai ma'arif sarolangun. El-Jaudah: Journal of Arabic Language and Literature Education, 1 (2), 59-68. 